\title{
Glucose Inhibits Replication of Cultured Human Endothelial Cells
}

\author{
R.W. Stout \\ Department of Geriatric Medicine, The Queen's University of Belfast, Belfast, Northern Ireland, UK
}

\begin{abstract}
Summary. Diabetes is an important risk factor for atherosclerosis but the mechanism of the risk is unknown. As endothelial injury is considered to be an early event in the development of atherosclerosis, the effect of glucose on endothelial cell replication was studied. Concentrations of glucose of $11.2,16.8$ and $22.4 \mathrm{mmol} / \mathrm{l}$ inhibited DNA synthesis in cultured human umbilical venous endothelial cells by $8.1 \pm 10.8$, $24.3 \pm 8.8$ and $30.9 \pm 7.4 \%$, respectively. Glucose also inhibited the proliferative response of endothelial cells to experimental wounds in the cell layer. Sorbitol $(22.4 \mathrm{mmol} / 1)$ inhibited en-
\end{abstract}

dothelial cell DNA synthesis by $50 \pm 13.6 \%$, but mannitol ( $22.4 \mathrm{mmol} / \mathrm{l}$ ) inhibited DNA synthesis by only $3 \pm 24.3 \%$. It is suggested that in diabetic subjects, high blood glucose levels may cause endothelial injury, or inhibit its repair, and hence allow the exposure of the arterial media to plasma and its constituents.

Key words: Glucose, endothelial cells, DNA, cell culture, diabetes mellitus, atherosclerosis.
Although atherosclerosis is more common in diabetic patients than in normal subjects, the exact relationship between the metabolic abnormalities of diabetes and the pathogenesis of the vascular disease remains unclear [1]. Risk factors for atherosclerosis in the general population, including hypertension and abnormal serum lipids, are related to atherosclerosis in diabetic patients in the same way as in normal subjects, but do not appear to explain entirely the excess risk of atherosclerosis in diabetes. The development of large vessel disease in diabetic patients does not appear to be prevented by available methods of treating diabetes [1]. Epidemiological studies suggest that there is a factor or factors unique to diabetes which is responsible for the increased incidence of large vessel disease [2].

Two cells of the arterial wall are closely associated with the development of atherosclerosis [3]. Endothelial cells form the lining of the inner part of the artery and are considered to act as a barrier, preventing the entry of plasma constituents into the inner part of the arterial wall. Smooth muscle cells comprise the media of the artery, and are also found in small numbers in the normal intima. A current theory suggests that the initial change in atherosclerosis is the development of an injury or alteration to the endothelial barrier [4]. This allows plasma to enter the inner intima and media where smooth muscle cells are exposed to substances including a fac- tor from platelets [5] and insulin [6,7] which stimulate their proliferation. If exposure is prolonged an atherosclerotic lesion with lipid, connective tissue and thrombosis develops.

Much attention has been paid to factors which stimulate arterial smooth muscle cell proliferation [5-8]. Of equal importance are factors which inhibit endothelial cell proliferation and hence retard the healing of injury to the endothelium. The major metabolic abnormality in diabetes is a high plasma glucose, and therefore the effect of glucose on human endothelial cell replication was studied.

\section{Methods}

Human endothelial cells were cultured from umbilical vein by a modification of the methods of Jaffe et al. [9] and Gimbrone et al. [10] as previously described [11]. Briefly, umbilical cord was obtained within $24 \mathrm{~h}$ of delivery. The umbilical vein was identified, cannulated and, after being flushed free of blood with phosphate-buffered saline (PBS) infused with a solution of collagenase (0.025\% in PBS). Ten minutes later the collagenase solution was flushed from the vein together with the freed endothelial cells. The cells were concentrated by centrifugation and were then placed in plastic tissue culture flasks (Becton Dickinson, Wembley, Middlesex, UK) in medium 199 (Gibco-Biocult, Paisley, Scotland, UK) supplemented by $20 \%$ pooled human serum (obtained from the Northern Ireland Blood Transfusion Service). Cell growth was seen within $6 \mathrm{~h}$. Endothelial cells could 

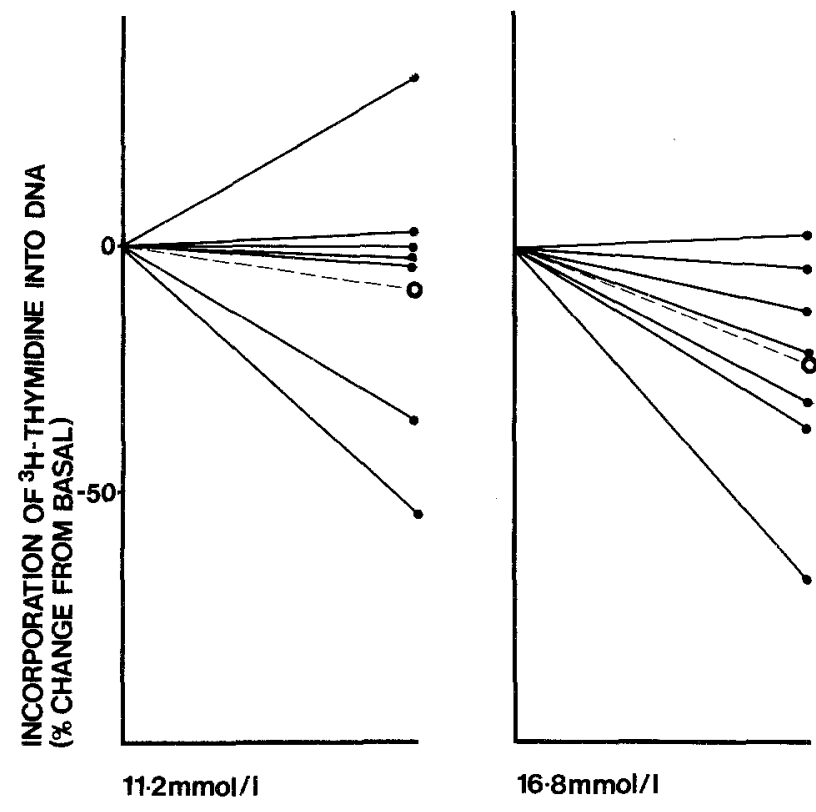

GLUCOSE

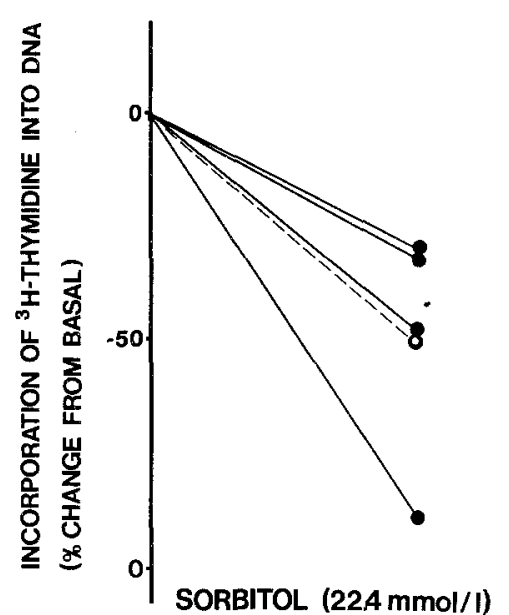

Fig. 2. Effect of sorbitol on incorporation of ${ }^{3} \mathrm{H}$-thymidine into DNA in cultured human umbilical venous endothelial cells. The mean change in DNA synthesis was $-50 \pm 13.6 \%(p<0.025)$

identified by their immunological and ultrastructural characteristics as described previously [11].

For the experiments, endothelial cells derived from three different umbilical cords were passed into twelve $30 \mathrm{~mm}$ Petri dishes (Falcon) and grown to sub-confluency. This was the first subcultivation of these cells. The medium was then changed, the six control dishes continuing in standard medium with $20 \%$ pooled human serum and glucose $(5.6 \mathrm{mmol} / \mathrm{l})$ and the other six dishes containing medium, serum and glucose concentrations $(11.2,16.8$ or $22.4 \mathrm{mmol} / \mathrm{l})$, which are representative of those found in diabetic patients under varying degrees of control. Each experiment tested one concentration of glucose against the control medium. After exposure to the test media for $24 \mathrm{~h}$, $1 \mu \mathrm{Ci}$ of ${ }^{3} \mathrm{H}$-thymidine (Radiochemical Centre, Amersham, UK) was added to each dish. Two hours later the medium was removed, the cells were freed from the dishes by trypsinization, DNA was isolated and radioactivity estimated as described previously [11]. The results were expressed in terms of cell protein measured by the method of Lowry et al. [12]. For each experiment the mean of the six dishes exposed to the high glucose concentration was expressed as a percen-

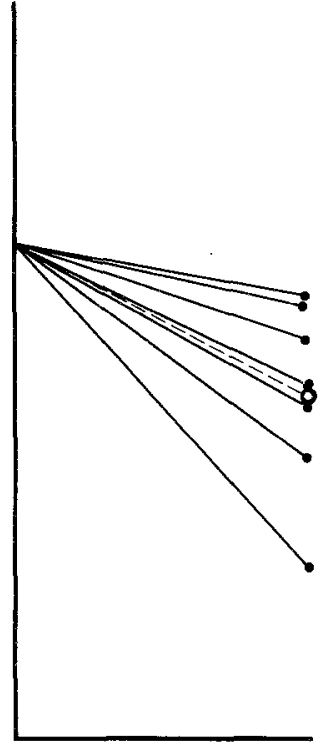

$22.4 \mathrm{mmol} / \mathrm{I}$
Fig. 1. Effect of three concentrations of glucose on incorporation of ${ }^{3} \mathrm{H}$-thymidine into DNA in cultured human umbilical venous endothelial cells. With glucose $(11.2 \mathrm{mmol} / \mathrm{l})$ the change in DNA synthesis was: -8.1 $\pm 10.8 \%($ mean $\pm \mathrm{SEM} ; p>0.20)$ with $16.8 \mathrm{mmol} / 1:-24.3 \pm 8.8 \%$ $(p<0.025)$ and with $22.4 \mathrm{mmol} / \mathrm{l}$ : $-30.9 \pm 7.4 \%(p<0.005)$ tage change of the mean of the control dishes. For each concentration of glucose the experiment was repeated on seven occasions.

To test the effect of glucose on the proliferation of endothelial cells in response to experimental wounds, $30 \mathrm{~mm}$ Petri dishes containing almost confluent endothelial cells were scraped in two parallel lines with a $5 \mathrm{~mm}$ wide stainless steel spatula. The scraped cells were washed off and the medium changed to standard medium (six dishes) and medium containing glucose $(22.4 \mathrm{mmol} / \mathrm{l})$ (six dishes). After $24 \mathrm{~h}$, $48 \mathrm{~h}$ or 7 days $1 \mu \mathrm{Ci}$ of ${ }^{3} \mathrm{H}$-thymidine was added for $2 \mathrm{~h}$ and the cells processed as before.

In another series of experiments, sorbitol $(22.4 \mathrm{mmol} / \mathrm{l})$ or mannitol $(22.4 \mathrm{mmol} / 1)$ instead of glucose was added to the medium.

Statistical analysis was performed as follows. The significance of the seven replicate experiments was tested by paired t-test. As the results may not have been normally distributed, significance was also tested by the two-tailed binomial test and the Wilcoxon signed rank test. The significance levels were the same using all three tests and only the paired t-test results are reported here. A least-squares linear correlation between the change in the DNA synthesis and the increment in giucose concentration was calculated.

\section{Results}

The results illustrate a progressive depression of DNA synthesis in human endothelial cells exposed to increasing concentrations of glucose (Fig. 1). With glucose $(11.2 \mathrm{mmol} / \mathrm{l})$ the mean change was $-8.1 \pm 10.8 \%$ (mean \pm SEM; $p>0.20)$; with glucose $(16.8 \mathrm{mmol} / \mathrm{l})$ $-24.3 \pm 8.8 \% \quad(p<0.025)$; and with glucose $(22.4$ $\mathrm{mmol} / \mathrm{l})-30.9 \pm 7.4 \%(p<0.005)$. When the mean percentage change in DNA synthesis was related to the increment concentration, there was a highly significant linear correlation $(r=-0.99 ; p<0.01)$. In cell layers that had been subjected to experimental wounds, glucose $(22.4 \mathrm{mmol} / \mathrm{l})$ had a similar inhibitory effect on DNA synthesis. This varied from a change of $-29 \%$ (mean of three experiments) $24 \mathrm{~h}$ after wounding to 
$-54 \%$ (mean of two experiments) 7 days after wounding.

When cells were exposed to sorbitol $(22.4 \mathrm{mmol} / \mathrm{l})$, the mean inhibition of DNA synthesis in four experiments was $-50 \pm 13.6 \%(p<0.025$; Fig. 2$)$. Sorbitol also inhibited DNA synthesis (mean change $-68 \%$ at $24 \mathrm{~h}$ after wounding) in endothelial cell layers subjected to experimental wounds. However exposure of the cells to mannitol $(22.4 \mathrm{mmol} / \mathrm{l})$ in five experiments resulted in a mean inhibition of DNA synthesis of $-3.0 \pm 24.3 \%$ $(p>0.45)$.

\section{Discussion}

These experiments show that glucose in increasing concentrations causes inhibition of incorporation of labelled thymidine into DNA in cultured human endothelial cells. This occurred both in subconfluent cell layers and in cell layers that had been subjected to experimental wounds. It has been suggested that the latter experimental model is more relevant to endothelial repair in vivo [13]. Although cell counts were not performed, other workers have found that the incorporation of thymidine into DNA reflects the number of cells when proliferation of endothelial cells has been studied [13]. These findings contrast with the effect of glucose on other cultured cells: glucose has no effect on smooth muscle cell proliferation but stimulates fibroblast proliferation [14]. The mechanism of the inhibition of endothelial cell proliferation by glucose may be related to its metabolic effects, to the osmotic effects of high glucose concentrations, or to cyclic AMP, a potent inhibitor of endothelial cell proliferation [15]. As reported with fibroblasts and smooth muscle cells [14] sorbitol, a nonutilizable corbohydrate, had similar effects to glucose but mannitol had no effect. However, endothelial cells do not have the capacity to convert glucose to sorbitol [16] so it is likely that extracellular effects of both molecules are involved in the inhibition of cell replication. However, the lack of effect of mannitol on endothelial cell proliferation argues against hyperosmolarity being the explanation for the effect of glucose. Detailed studies of the osmolarity of the culture medium are needed to confirm or deny hyperosmolarity as a mechanism for glucose's effect on endothelial cell proliferation.

These results, if they apply to endothelial cells in vivo, suggest that high plasma glucose concentrations could inhibit endothelial cell replication. Glucose may, therefore, cause endothelial injury, perhaps by inhibiting the normal turnover of endothelial cells or, if an injury is caused by other means, the presence of a high glucose concentration may inhibit the repair of the endothelium. A recent study of alloxan-diabetic rabbits has shown aortic endothelial damage in hyperglycaemic animals [17]. A high glucose concentration could therefore contribute to the development of atherosclerosis by increasing the exposure of the subintimal tissues to plasma. Plasma constituents, including the platelet derived growth factor and insulin would then be able to stimulate the proliferation of medial smooth muscle cells and lipoproteins could be deposited in smooth muscle cells or macrophages.

This hypothesis would be consistent with epidemiological evidence on the relationship of large vessel disease to diabetes [1]. Although diabetic patients are more prone to atherosclerosis than normal subjects, the relationship between blood glucose and atherosclerosis is not linear but more in the nature of a threshold effect [18]. Risk factors for atherosclerosis in the general population are related to atherosclerosis in diabetes but do not account for the excess incidence of this disorder in diabetic patients [2]. High plasma insulin levels are prospectively related to coronary artery disease in the general population [19-21].

If this hypothesis is correct, prevention of large vessel disease in diabetic patients would be achieved by a reduction of blood glucose levels without the use of excess insulin concentrations. In non-insulin dependent diabetic patients this could be achieved by weight reduction and exercise. For insulin-requiring diabetic patients the development of new methods of insulin delivery resulting in insulin concentrations nearer the physiological should be encouraged.

Acknowledgements. The skillful technical help of Mr. J.Donnelly and Mrs. N.Copeland, and the careful preparation of the manuscript by Miss A. Best is gratefully acknowledged. Supported in part by a grant from the Department of Health and Social Services (Northern Ireland).

\section{References}

1. Stout RW (1981) Blood glucose and atherosclerosis. Arteriosclerosis 1: $227-234$

2. Kannel WB, McGee DL (1979) Diabetes and cardiovascular risk factors: the Framingham study. Circulation 59: 8-13

3. Ross R (1981) Atherosclerosis: A problem of the biology of arterial wall cells and their interactions with blood components. Arteriosclerosis 1: 293-311

4. Ross R, Glomset JA (1976) The pathogenesis of atherosclerosis. N Engl J Med 295: 369-377, 420-425

5. Ross R, Vogel A (1978) The platelet-derived growth factor. Cell 14: $203-210$

6. Stout RW, Bierman EL, Ross R (1975) Effect of insulin on the proliferation of cultured primate arterial smooth muscle cells. Circ Res 36: 319-327

7. Pfeifle B, Ditschuneit H (1981) Effect of insulin on growth of cultured human arterial smooth muscle cells. Diabetologia 20: $155-158$

8. Koschinsky T, Bunting CE, Schwippert B, Gries FA (1981) Regulation of diabetic serum growth factors for human vascular cells by the metabolic control of diabetes mellitus. Atherosclerosis 39 : 313-319

9. Jaffe EA, Nachman RL, Becker CG, Minick GR (1973) Culture of human endothelial cells derived from umbilical veins. Identification by morphologic and immunologic criteria. J Clin Invest 52: $2745-2756$

10. Gimbrone MA Jr, Cotran RS, Folkman J (1974) Human vascular endothelial cells in culture. J Cell Biol 60: 673-684 
11. Taggart H, Stout RW (1980) Control of DNA synthesis in cultured vascular endothelial and smooth muscle cells - response to serum, platelet-deficient serum, lipid-free serum, insulin and oestrogens. Atherosclerosis 37: 549-557

12. Lowry OH, Rosebrough NJ, Farr AL, Randall RJ (1957) Protein measurement with the Folin phenol reagent. J Biol Chem 193: 265-275

13. Schwartz SM, Gajdusek CM, Selden SC III (1981) Vascular wall growth control: the role of the endothelium. Arteriosclerosis 1: $107-126$

14. Turner JL, Bierman EL (1978) Effects of glucose and sorbitol on proliferation of cultured human skin fibroblasts and arterial smooth muscle cells. Diabetes 27: 583-588

15. Stout RW (1982) Cyclic AMP: a potent inhibitor of DNA synthesis in cultured arterial endothelial and smooth muscle cells. Diabetologia 22: $51-55$

16. Boot-Handford RP, Heath H (1978) The absence of sorbitol pathway activity in primary cultures of human umbilical cord vein endothelial cells. IRCS Med Sci Biochem 9: 451 (Abstract)

17. Dolgov VV, Zaikina OE, Bondarenko MF, Repin VS (1982) Aortic endothelium of alloxan-diabetic rabbits: a quantitative study using scanning electron microscopy. Diabetologia 22: 338-343

18. Fuller JH, Shipley MJ, Rose G, Jarrett RJ, Keen H (1980) Coro- nary-heart-disease risk and impaired glucose tolerance. Lancet 1: 1373-1376

19. Pyorala K (1979) Relationship of glucose tolerance and plasma insulin to the incidence of coronary heart disease: results from two population studies in Finland. Diabetes Care 2: 131-141

20. Welborn TA, Wearne K (1979) Coronary heart disease incidence and cardiovascular mortality in Busselton with reference to glucose and insulin concentrations. Diabetes Care 2:154-160

21. Ducimetiere P, Eschwege E, Papoz L, Richard JL, Claude JR, Rosselin G (1980) Relationship of plasma insulin levels to the incidence of myocardial infarction and coronary heart disease mortality in a middle-aged population. Diabetologia 19: 205-210

Received: 12 January 1982

and in revised form: 19 July 1982

Professor R. W. Stout

Department of Geriatric Medicine

The Queen's University of Belfast

Whitla Medical Building

97 Lisburn Road

Belfast BT9 7BL

Northern Ireland, UK 